\title{
The Symbolic Interaction of Tandhe' in Sumenep Madurese
}

\author{
Mohammad Ali Al Humaidy \\ Institut Agama Islam Negeri Madura \\ email: gusmalhum@gmail.com \\ Eko Ariwidodo \\ Institut Agama Islam Negeri Madura \\ email: eko.ariwidodo@iainmadura.ac.id
}

\begin{abstract}
Local culture everywhere presents meaning space as a guideline for people's lives, even the presence of tradition can be a medium of social transformation. The tandhe' as one of the local cultural treasures in Sumenep Madura, emerged as an appreciation of past civilizations that believe that tandhe' is not a mere spectacle but also as a communication medium that contains the values of goodness. Signs implicitly or explicitly important to learn because it often contains the essence of da'wah which calls on humans to remember God. Tandhe' as a manifestation of local wisdom will be an effective communication medium for building communities when properly packaged, because cultural anomalies can occur at any time. The researcher uses a qualitative approach in the form of field research so that researchers can directly make observations and even participate in contributing ideas as feedback from informants ideas. The presence of tandhe' has until now experienced a shift in the function and purpose of tandh' itself. The ancient kings tandhe' functioned as the media for the propaganda used by Walisongo in order to spread the teachings of Islam. The religious value of the tandhe ' began to fade because the lovers of the tandhe' began to abandon the teachings taught by the Walisongo. Tandhe' at the moment
\end{abstract}


is more dominant in the nature of entertainment which aims only for worldly purposes only. Tandhe' essentially has a symbolic communication used by Walisongo in preaching Islam to the community which is also a symbol of tirakat by human.

[Budaya lokal di mana-mana menghadirkan ruang makna sebagai pedoman hidup masyarakat, bahkan keberadaan tradisi dapat menjadi media transformasi sosial. Budaya tandhe' sebagai salah satu khazanah budaya lokal di Sumenep Madura, muncul sebagai apresiasi terhadap peradaban masa lalu yang meyakini bahwa tandhe' bukan sekedar tontonan, tetapi juga sebagai media komunikasi yang mengandung nilainilai kebaikan. Tanda-tandanya secara implisit maupun eksplisit penting untuk dipelajari karena seringkali mengandung esensi dakwah yang mengajak manusia untuk mengingat Tuhan. Tandhe' sebagai perwujudan kearifan lokal akan menjadi media komunikasi yang efektif untuk membangun masyarakat apabila dikemas dengan baik, karena anomali budaya dapat terjadi kapan saja. Peneliti menggunakan pendekatan kualitatif berupa penelitian lapangan, sehingga peneliti dapat langsung melakukan observasi bahkan ikut serta menyumbangkan gagasan sebagai umpan balik dari gagasan informan. Kehadiran tandhe' hingga saat ini mengalami pergeseran fungsi dan tujuan tandhe' itu sendiri. Raja-raja kuno masalah lalu, tandhe' berfungsi sebagai media dakwah yang digunakan oleh Walisongo untuk menyebarkan ajaran Islam. Nilai religius tandhe' mulai pudar karena para pecinta tandhe' mulai meninggalkan ajaran yang diajarkan oleh para Walisongo. Tandhe' pada saat ini lebih dominan bersifat hiburan yang bertujuan hanya untuk kepentingan duniawi saja. Tandhe' pada hakikatnya memiliki komunikasi simbolik yang digunakan Walisongo dalam dakwah Islam kepada masyarakat yang juga merupakan simbol tirakat oleh umat manusia.]

Keywords: symbolic interaction; communication; $d a$ 'wah; thande'

\section{Introduction}

This study departs from an understanding that each tradition does not stand alone because tradition is born based on historical dynamics and transformative dialectics of its time. Local culture everywhere presents meaning space as a 'guidelines' for people's lives, even the presence of tradition can be a medium of social transformation. The art of tandhe' as one of the local cultural treasures in Sumenep Madura, emerged as an appreciation of past civilizations that believe 
that tandhe' art is not only a spectacle but also a communication medium that contains good values. As a literary work, the sign implicitly or explicitly contains the essence of $d a$ 'wah (trancendental) which calls on humans to remember God and always do good.

Tjetjep Rosmana's state that as a literary work is always attached to it the potential educational values to build a universe of personal and individual personality. Values in an old literary work, both oral and written are the essential elements of the literary work as a whole. Therefore, expressing the values contained in songs and folklore, will indirectly provide an understanding of the socio-cultural background of the supporting communities in which the story grows and develops and is guided by the supporting community.

Therefore, tandhe' as a manifestation of local wisdom will become an effective communication medium to build society when it is properly packaged, because cultural anomalies can occur at any time. Kuntowijoyo stated that culture can become functional if its symbols and norms are no longer supported by social institutions, or by the mode of social organization of that culture. Cultural contradictions can occur so that it can paralyze its social foundations.

Madura, which is sociologically majority Muslim and cannot be separated from Javanese culture or tradition, will find a mutualist relationship between Javanese culture and Islamic values. The relationship between adat and Islam has given birth to various forms of religious expression as a reflection of traditional teachings. The same thing happened with traditional expression as a reflection of Islamic teachings. Islam is faced with a conflict or dialectic with the local culture where Islam is developing. In the dialectical process a mutual dialogue takes place between universal Islam and particular cultures, which give birth to what is called a distinctive Islamic culture.

However, in reality tandhe' art in Sumenep which morphed before independence, the values (meaning) of $d a$ 'wah have not been down to earth because tandhe' is still interpreted as an entertainment art. The petandhe' (tandhe player term) impressed the invited guests. More extreme, if based on the fatwa of some scholars that tandhe' is forbidden, because of the interaction of men and women (between players and spectators). 
Based on a literature review, this research is interesting to carry out because no one has studied or examined aspects of the meaning of the tandhe' art movement as a means of preaching communication in building civilization. The construct of this study examines the meaning of the tandhe' movement as a symbolic interaction model of da'wah communication and does not examine aspects of Islamic law to the tandhe' tradition.

\section{Methods}

Judging from the research themes, we used a qualitative approach in the form of field research so that researchers could directly make observations and even participate in contributing ideas as feedback from informants' ideas. This approach provides broad opportunities for researchers to hold direct interactions or face to face interactions with informants and stakeholders. Qualitative research in terminology is research that is empirical in nature and its analysis is based on existing data. The object of this qualitative research is the art of sign, the research procedure will produce descriptive data in the form of written or oral words of people and their behavior.

Data analysis techniques use a descriptive analysis approach that illustrates the dynamics of tandhe' art emerge to this day, by reflecting the construction of sign art values as a symbolic interaction model of da'wah communication. Referring to Miles and Huberman's opinion that data analysis consists of three activities that occur simultaneously: data reduction, data presentation, and drawing conclusions. Data analysis is intended as a process of comparing findings obtained from several places, as well as integrating between sites. The findings obtained from the data about tandhe' art at Sumenep are arranged in categories and themes, analyzed conceptually inductively and made substantive explanations arranged into certain propositions which then become substantive theories.

\section{Result}

This analysis is intended to compile a systematic conception based on the results of data analysis and narrative theoretical 
interpretations in the form of cross-site propositions which are then used as material to develop the findings of substantive theory.

\section{Symbolic interaction}

The theory of symbolic interactionism which is the result of Mead's thought construction, regarding the use of symbols ${ }^{1}$ relating to emotions, social values, and thoughts that are believed to be able to form the concept ${ }^{2}$ of himself (selfconcept) in building social action. Therefore the role of individuals in interaction is symbolic and influences social actions $^{3}$ which are basically inseparable from religious social symbols about what is meant in building their social world. ${ }^{4}$

Human behavior must be assessed based on their respective subjective, in the theory of interactional symbolic social reality is part of the process, not something that is static, society can be seen from the actions and interactions within it. Basically every human being is not a 'finished product' but a product that 'will be', therefore symbolic interaction discusses the concept of self and grows based on the 'negotiation of meaning' for the actions of others, humans act based on the meaning of the process of ongoing interaction. ${ }^{5}$

Symbolic interactionism focuses on the process of meaning of social reality by using social symbols and emphasizes the actions (acts) and the individual role of the dancers 'sign' to something that is considered meaningful (thing) and become social value. Therefore, the act of the dancer 'sign' contains social values that can be perceived by the community, as a value system that is believed to be able to move one's actions and behavior. Symbolic interaction according to interactional perspective, is one of the perspectives in communication studies, which is perhaps the most "humanist" in nature. Where, this

\footnotetext{
${ }^{1}$ Douglas, Pengantar Sosiologi, trans. Kamanto Sunarto (Jakarta: Penerbitan Fakultas Ekonomi Universitas Indonesia, 2004), 35.

${ }^{2}$ Herbert Blumerand George Herbert Mead, Pengantar Sosiologi Mikro, trans. Agus Salim (Yogyakarta: Pustaka Pelajar, 2008), 11.

${ }^{3}$ Bernard Raho, Teori Sosiologi Modern (Jakarta: Prestasi Pustaka, 2007), 110-111.

${ }^{4}$ Siti Machmiyah, "Interaksi Simbolik Santri Pondok Pesantren Al-Amin," Jurnal Kajian Ilmu Komunikasi 45, no. 1 (2015): 25.

${ }^{5}$ Mulyana, Metode Penelitian Komunikasi (Bandung: PT Remaja Rosdakarya, 2007), 56.
} 
perspective really emphasizes the majesty and masterpieces of individual values over the influence of existing values so far. This perspective considers every individual in himself to have the essence of culture, interact in the middle of the social community, and produce meaning "ideas" that are agreed collectively. In the end, it can be said that every form of social interaction carried out by each individual, will consider the individual's side, this is one of the characteristics of the interactional perspective which is symbolic interactionism. ${ }^{6}$

\section{Da'wah communication}

Da'wah communication theory definitively, can be interpreted as a persuasive rhetorical process carried out by the $d a{ }^{\prime} i$ communicator $\left(d a^{\prime} i\right)$ to disseminate messages containing religious values, both in verbal and non-verbal forms, to the congregation to obtain good in the world and the hereafter. ${ }^{7} \mathrm{Da}$ 'wah communication acts as a framework of thought (paradigm) for perpetrators of $d a$ 'wah to provide clearer direction and focus on a target object contained in da'wah communication. Therefore, in the $d a$ 'wah communication is inseparable from the discussion of its components, both core components and supporting components. The core components include: dai, mad'u, messages and methods. While the supporting components include: organization, economy, social, culture, government policies, or support from community groups. ${ }^{8}$

Departing from a paradigm of communication and $d a$ 'wah that is the interactional paradigm which has the main characteristics highlighting individual values above all other influences, then this research becomes important. The reason is, humans have the essence of culture, interconnected, social and have ideas. Thus, every form of social interaction begins and ends by considering the human self.

\footnotetext{
${ }^{6}$ Ardianto, Elvinaro dan Bambang Q-Anees, Filsafat Ilmu Komunikasi (Bandung: Simbiosa Rekatama Media, 2007), 40

${ }^{7}$ Bambang S. Ma'arif, Komunikasi Dakwah, Paradigma untuk Aksi (Bandung: Remaja Rosdakarya,2010), 3.

${ }^{8}$ Ibid., 7.
} 


\section{The Origin of Tandhe}

According to Abdurrahman, an art figure in Saronggi subdistrict, the term tandhe' came from the Madurese language, that is someone who dances while dancing (nandhang), the main thing is that tandhe' is specifically for women. This was also conveyed by Rausi, a researcher about tayub in Sumenep, the Madurese community used the term tandhe' refers to two things, namely; first, tandhe' is an art. Second, tandhe' is identical to a woman because tandhe' refers to female dancers at tayuban events. In addition, because in tayuban a woman who dominates the tayuban event, so the tayuban event is identical with the term of tandhe'. ${ }^{9}$

Abdurrahman added that the tandhe was sinden, inside sinden there were female vocal voices and male vocal voices, in general karawitan in Sumenep knew songs and music because they had existed since before independence. Sumenep's music in 1957 was original, both his gamelan and song in Madurese were called kejung which had its own standards, such as nyuko nyethak, for example sottanangngah esassa'ah, kaserbiten norok lorong, emannah se tapesa'ah, kareh abit alongpolong. ${ }^{10}$

But unfortunately the paparekan is not recorded by Madura poets, unlike in Javanese which is written in books such as gending song walang kekek created by Ki Narto Sabdo. Rahman stated that the art figure in Kacongan, the term tandhe' according to the story of the past, mon tak kontan tak endhek (if it was not cash, it would not be wanted). He added that between tandhe' and tayub means the same thing, a woman who can dance and dance, but is different from karawitan, which means gamelan beater. If tandhe' is a sinden se ngijung (vocalist) and dancing, while karawitan is a gamelan beater and other instruments such as Sumber Bunga, Seribu Doyo and other. ${ }^{11}$

Sinden or tandhe' used to be atolong, tandhe' now alako. The dark history of a tandhe' began with economic pressure at the time. The difficulty of life at that time was a compulsion factor to become a sinden or tandhe', indeed at first not all families accepted the profession as a

\footnotetext{
${ }^{9}$ Abdurrahman, Interview, in Sumenep, May 1, 2019

${ }^{10}$ Abdurrahman, Ibid.

${ }^{11}$ Rahman, Interview, in Sumenep May 30, 2019.
} 
tandhe' but gradually because of being a family livelihood then the family could not forbid even themselves and the family dependent on this tandhe' profession. Some people see the profession as tandhe' is a profession that is less dignified. Although isolated from a society that has a certain set of values, morals and ethical standards, a tandhe' will not stop dancing and singing, because they know how they should deal with living in a social life with a patriarchal culture that is thick in Madurese society.

\section{The Dynamics of Tandhe'}

In the history of performing tandhe' as art in Sumenep, the most information says that tandhe' began in Dasuk District, Bukabu village. Not without reason why tandhe' first appeared in Dasuk, this is because the development of Javanese art in Madura began during the reign of Setiadiningrat, Adipati Setiadiningrat palace located in the Southwest, Bukabu. Because Setiadiningrat's dedication to Majapahit was so strong that Majapahit cultures were brought to Sumenep, such as the Sinden dance which was a Majapahit culture that flourished in the Sumenep palace at that time.

The original relics of the mask, mask puppet dance. Why is that, the real proof until now is the mask dance in Dasuk. The mask is the same as the unfortunate mask or jabung mask. So according to Sumenep researchers both in terms of movement and clothing have similarities between the art of mask dance in Dasuk with mask dance in Malang. However, over time, the art of mask dance began to develop outside the palace resulting from the imagination of an artist so that the mask dance has two versions, namely the dance that developed in the palace and mask dance that developed outside the palace. Although the tandhe' dance and the mask dance have the same origins that are Javanese traditions brought to Madura, but there are different things in both the mask dance is a manifestation of wayang kulit or wayang purwo, while sinden or tandhe' in terms of pantun or paparekan merges to uphold the invitor (host) and pray for the bride and groom to be sure, mawaddah warahmah, for example the bride and groom's wedding has sat in a row, at the end it is like "mamatannah dari benjer arloji potong 
se konah, pangantannah ampon ajejer kaule sakancah moji mandher rokonah". The standard is spoken when the pesinden perform.

According to Subaidi, the beginning of the emergence of tandhe' dance in Madura during the era of the kings in Sumenep, which originated initially from the Districts of Dasuk, Tobela and Panilen. In the past a pesinden and gamelan player had a teacher and a school, but now there is none. ${ }^{12}$ This was also conveyed by K. Saleh that in the old days a pesinden (tandhe') had to have a teacher because at that time it was not easy to be a pesinden because he had to understand the meaning of each movement in the dance tandhe'. In fact, in the time of walisongo when a person wanted to learn the art of dance tandhe', then he must be satisfied first for a week besides that he must master 30 letters, namely letters Alif to Ya (in Arabic).

Proof of the existence of tandhe' dance since ancient times is also said by Shaleh that at that time, Sumenep had been attacked by a kingdom led by Ken Arok or Alesan, who in the war when viewed from the number of troops and weapons, Sumenep would have lost, but before the war happened Ken Arok's troops were provoked and seduced by the tandhe' so that the tandhe' succeeded in taking the weapons of the troops led by Ken Arok which caused the Sumenep forces to win the war. ${ }^{13}$

The existence of tandhe' dance during the palace in Sumenep was also explained by Mahmud, a figure of excitement in the Kalianget District, that the developer of Javanese dance, including tandhe', in the Sumenep palace was a king who was at the same time the cleric and cleric was Kiai Pekkeh because besides his broad religious insight also as an artist. Kiai Pekkeh is also a teacher of Muhammad Saud who is well-known by the nickname Bindere Saud. ${ }^{14}$ Mahmud added that although Bindere Saud had become a king, the relationship between the two remained intact. ${ }^{15}$ Kiai Pekkeh not only taught and developed the religion of Islam in Sumenep but also Islamized art which had developed in previous eras. Islamized art is often displayed at court

\footnotetext{
${ }^{12}$ Subaidi, Interview, in Sumenep May 20, 2019.

${ }^{13}$ Shaleh, Interview, in Sumenep, May 24, 2019.

${ }^{14}$ Mahmud, Interview, in Sumenep, May 23, 2019.

${ }^{15}$ Mahmud, Interview, in Sumenep, May 23, 2019.
} 
events. Because of his fame, Kiai Pekkeh, he was not only invited to the court and the Sumenep community, but was also invited to the island of Java to be able to display his art and teach it to the Javanese people. So it is very popular if the stories around tandhe' present stories about the kingdom. As also stated by Zulkifli that in the era of the palace, tandhe' in addition to being entertainment at events at the palace was also a tool to get around the opponent. Like when there was a dispute between the Sumenep palace and Sampang.

In contrast to some of the opinion figures above that tandhe' began to develop after Indonesian independence. This is as conveyed by Rahman, that the tandhe 'only appeared around 1950. The pure guardians of karawitan do not have a tandhe'. Tandhe' appeared to accompany shadow puppets (karawitan accompanied by wayang). Puppet is also to spread Islam like kalima sodo. ${ }^{16}$ But Rahman's statement was denied by K. Saleh, a tandhe' dance artist in the 70s, that tandhe' dance was already known in the Walisongo era, this was seen when a woman who wanted to learn tandhe' dance at that time had to fast for one The week above is awkward, in addition it must also master 30 letters, namely the letter Alif until Ya (in Arabic). ${ }^{17}$

Rahman added that now the wedding celebration invites a sinden or tandhe' which is held using the stage, but if in the past the tandhe' performance does not use the stage because it usually only uses the home page. The oldest tandhe' in Sumenep came from Batu Belah village, district of Dasuk named Mistiyah (pass away) was a woman who had not received formal education to be a symbol of tandhe' in the Sumenep area around the 70-80s. Become tandhe' is a part of his life. A tandhe' is a cultural art performer who is famous for the independence of his voice and the beauty of his body so that when dancing makes others fascinated. ${ }^{18}$

Mon ta' pasra jek alako gebey, a phrase commonly spoken by the people of Sumenep so that if they do not have sufficient funds then

\footnotetext{
${ }^{16}$ Rahman, Interview, in Sumenep, May 30, 2019.

${ }^{17} \mathrm{~K}$. Saleh, Interview, in Sumenep, May 24, 2019.

${ }^{18}$ Rahman, Interview, in Sumenep May 30, 2019.
} 
do not hold celebrations that are large because if they hold a large event then they must bring tandhe' accompanied by musical instrument. So people who really invite or bring tandhe' are resigned people (capable people) according to the Madurese. All of the gending songs in Sumenep exist only because of the sharpness of the imagination of artists since the 1960s. For example in Java there is Sinomparijotho music by Sumenep artists traced and changed the word sinom to become senom. This was due to the lack of communication in earlier times, such as the song "lamong pinjang sun palastro, mon bule le" ampon depak ka omor, ojo kobur sa' jeroni ning bumi, bule je' kobur ning dalem bumi, ojo kirim kembang kambujo." Arriving in Madura, it was changed to Madura. For example, the relationship between romance between men and women uses the song above, basically the song system in Java. That is the power of the imagination of the Sumenep artists who then during the reign of Sultan Abdurahman, the arts had room to be improved both in terms of religious aspects and local content of Madura.

\section{Discussion}

In the era of Walisongo and the kingdom, tandhe' dance had a very strategic role, both aimed at preaching Islam and as a strategic tool to fool the enemies. In terms of preaching Islam, it can be seen when the walisongo give conditions to women who want to learn tandhe' dance must fast first for one week and must master 30 letters, namely the letter Alif to $Y a$, as stated by K. Saleh. This shows that the tandhe' dance at that time had high sacredity because learning tandhe dance' had to undergo a number of tithes plus the tandhe' dance movements that were exhibited always showed that only God Almighty (in the tandhe' dance movement will be explained in the next section). This is also seen in the view of Mr. Abdurahman that there seems to be a difference between sinden (tandhe') then with the present. Sinden in ancient times during the Walisongo were artists with artistic spirits and a very high appreciation of the dance and paparegan movements.

In addition, in the days of the kings also used the tandhe' as a strategy of war to deceive the enemy such as when there was a war between the Sumenep forces with the troops led by Ken Arok and the 
war between the Sumenep forces with the Sampang troops. At that time, the position of the tandhe' had a classy position in the community because of its role and sacredness in the midst of society. But over time the tandhe tradition has changed its function from the sacred-regelius to the secular profane and has changed from being aimed at preaching Islam to dance as merely entertainment.

In the $50 \mathrm{~s}$ to $80 \mathrm{~s}$, although the religious value of tandhe dance began to fade, tandhe' artists appreciation of tandhe art was still high, this was stated by Mistiyah, a tandhe' in the $80 \mathrm{~s}$, the passion I am in the art of tandhe' dance because I really do appreciate the art of tandhe', eventhough we are invited to a wedding, but that is not our goal. The tandhe' tradition in the 50s to 80s only exists in tandhe' artists held in the houses of tandhe' artists at a certain time with the aim only to appreciate and explore the tandhe' dance without any material elements. But with the passage of time, since the 90s the tandhe' tradition has begun to change from a tandhe performance' which upholds the value of the art itself to arts that are only entertainment, dance performance and spectacle.

This has happened since Wara a tandhe' in the 90s, has combined the art of dance tandhe' with dangdut (alike Indian song) and sling with dangdut songs with the aim of being able to sell in the market or with the hope of many tandhe' lovers inviting him so as to make a lot of money. The shift of roles and objectives in the tandhe' dance which is sacralistic to materialistic (profan) is in accordance with the theory presented by Maslow in Burhan Nurgiyantoro that there is a change in one's mindset about something because one's lifestyle is getting higher and more expensive. The increasingly high necessities of life, for example aesthetic needs, may not necessarily be achieved by everyone. However, once a person is able to meet those needs, the person concerned will feel more in need and try to fulfill further needs. Tandhe' dance in the $50 \mathrm{~s}$ to $80 \mathrm{~s}$, although the value of sacredness had diminished, it still maintained the manners that had been built before. This can be seen when staging tandhe' at the wedding ceremony that year a tandhe' from the house to the wedding venue did not go straight to the gamelan stage, but went to the kitchen first to encourage apoy, as 
the meaning of kulonuwon (asked permission) to the host. From the kitchen then sat on the terrace waiting for the sound of the sound from yogo or pangrawit. If there is a melody accompanied by the gending "ayak sapolo" then come down from the terrace and dance while singing or ngijung.

This is as conveyed by Abdurrahman that tandhe' art in the 50s to 80 s still had high manners and artistic value even though its religious value had begun to decline. For example, at a wedding when I sat down and there was a jurdang (midfielder) carrying penjung placed on me so that in honor of my host I went to a special place and danced according to the rules of dance art tandhe' right because because if the feet are not firm means not knowing dancing or nandheng, that was my experience as a teenager first. But if now tandhe' has lost its religious value and its artistic value is no longer aimed only at materialistic.

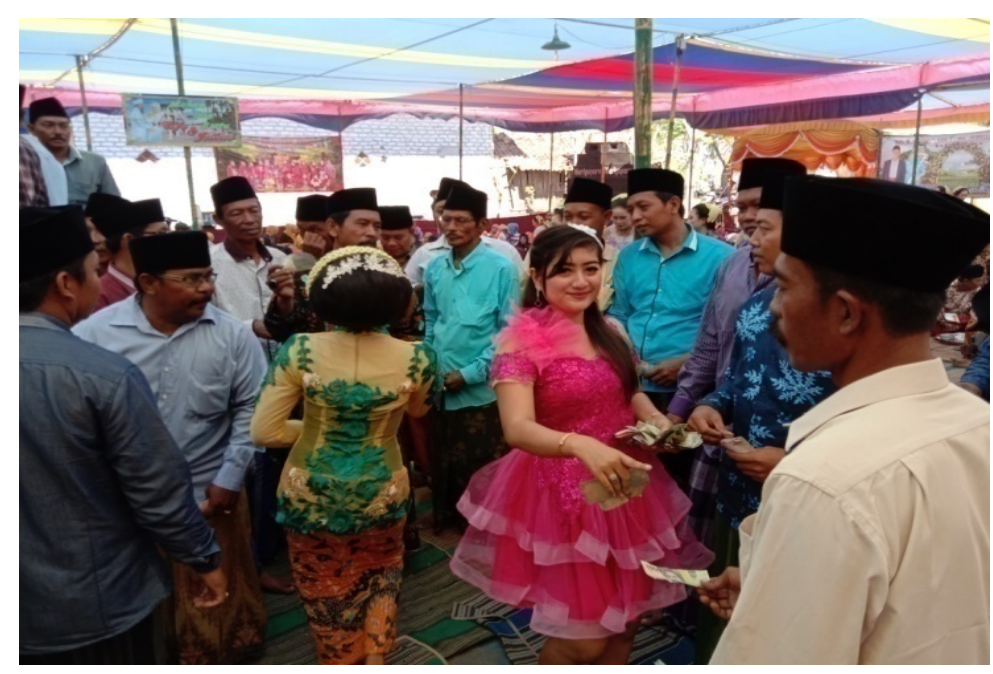

Copyright (c) 2020 by Karsa. All Right Reserved

DOI: $10.19105 /$ karsa.v28i1.1584 


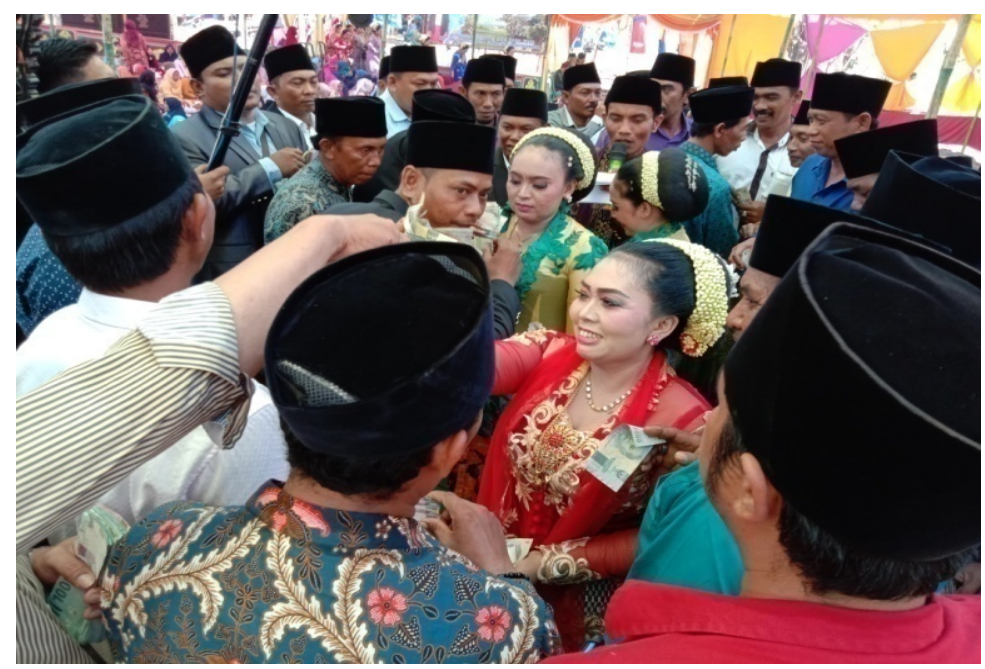

The face of the tandhe' performance at the present (2019)

Saronggi in the present day which developed since the 1990s, tandhe' is only limited to entertaining without any elements of preaching and is more concerned with personal interests, namely material income (money). This means that there has been a shift in value not only in tandhe' art but also in other art forms such as in Sumenep, the mocopat art scene that has a lot of meaning, the history of the prophet, tembang (song) of turma.

Early on the emergence of sinden, especially in Sumenep there was a 'rejection' and even the law was forbidden to appear and be watched by the pesantren because there were many elements that contradicted religious arguments such as the gathering of men and women, the sound of gamelan instruments and striking pesinden, so that it might have an impact negative between pesinden and the audience present. Whereas the beginning of the emergence of tandhe' dance art as the media of propaganda used by the Walisongo makes it easier for them to spread Islam through the art.

However, over time there has been a shift in the function and purpose of tandhe' dance from the sacred-regelius to the secular profane and has changed from being aimed at preaching Islam to dance 
as mere entertainment. The essence of tandhe' dance is only a handful of people who know about it, which causes pros and cons of the existence of tandhe' dance in Sumenep. This research describe the essence of tandhe' in terms of the meaning of the tandhe' movement and the meaning of tabbuen in the art of tandhe'. In the tandhe' dance movement as the Javanese say that the finger is jeburit interpreted by the poets of artists with the name of God and the position of the gongshaped foot to the right with the letter alif standing. Continue to form the letter "U" to the middle, with a dance count of 12345678 . The counting 1234 left foot, enter the gung (mole ka se agung or return to God) forms A (God), "I" (Ingsun), "U" (Urip). The counting 5678 feet back, from "U" (urip) to "I" (ingsun) and to "A" (Allah). It was only the poet's imagination like the story was just a legend that was untested, but it is believed to exist.

Other elements that contain the propaganda elements of the sling instrument before bekso tayub begins with the sinden of men who ngijung (singing) on gending Walisongo which tells everything in the instrument, for example those with bonang instruments, in gamelan there are bonang babuk, bonang elders. The contents of each bonang are 10 tones 1 cylindor nemcirolumo ( 5 tones) 2 places of the bonang 20 , if the artist in Sumenep bonang the goal must be a siparang nangwenang, 20 that is the nature of God, se lanjeng jiyeh nyamanah gegemben. The meaning of kiayi between pupils and kiayi gegemben, the body in your blood, je' paguli, means not to turn away from the power of Allah, and the method is 17 rakaat (with praying).

But today, many gamelan musicians do not understand the instruments of the gamelan and irregular gamelan instruments, thereby eliminating the meaning of the gamelan. In ancient times Saron meant "sopajeh nyembha ka dha' se sa jek nyembha ka se peron". To get to the platform there are 6 seeds in the pillars of faith. Gendang (the drum) sounds "pak buk pak buk." God is unseen. As the Prophet said, a friend asked, "Prophet because I don't see God, who do I want to worship?" So he was umi, umi, umi and father. So the father and mother were upheld by the Prophet but before the tandhe' indeed the prestige of wanting a song was just chanting without any tandhe'. 
Conceptually, every movement usually has a meaning like tandhe' macco karato (washing the fruits), its movements are like washing karato. Karato is fruit that is in the fields and then cleaned, if not cleaned properly it will intoxicate the host and the audience present. The meaning of flute 8 means the meaning of mindfulness to remember, the number of eight holes 8 in accordance with the sentence iqomah for prayer. The tandhe' konah (old style) movement is just a hand. For example: agei' sangge, ajemmor kalembeng. Now, there are various things. Likewise, the sinden and gamelan dances have elements of $d a$ 'wah values because the tandhe' is from the palace which has values of obedience to God and the royal family.

In addition, in the tandhe' dance also needs to be considered also the direction of the head that starts with the left direction and then leads to the right then leads up and ends down. This was also explained by Kiai Ismail that with the direction of the head alone it shows we are dhikr of láilăha illlah to Allah as the dzikir movement moves the Qadiriyah and Naqsabandiyah. ${ }^{19}$ Movement in the head in tandhe' dance is actually directly proportional to the $d h i k r$ which is popular among the Qadariyah and Naqsabandiyah orders.

There is an element of Sufism in the tandhe' movement because the existence of religious orders in the country is arguably one of the prominent religious symptoms of Islam. In this case there are those who argue that the tarekat has entered Indonesia along with the entry of Islam into Indonesia, in other words that the entry of Sufism into Indonesia is the same as the entry of Islam because Islam was brought by Sufis to Indonesia. According to A.H. Johns (an Australian philologist) in Simuh, the spread of Islam in Indonesia since the 13th century increasingly spread to various islands in Indonesia, mainly due to the efforts of the publishers of Islamic mysticism (or sufi). The publishers became members of the Islamic mysticism (the way of țariqat) who fled from Baghdad when the city was invaded by the Mongols in 1258 AD. ${ }^{20}$

\footnotetext{
${ }^{19}$ Ismail, Interview, in Sumenep June 7, 2019.

${ }^{20}$ Simuh, Sufisme Transformasi Tasawuf Islam ke Mistik Jawa (Yogyakarta: Yayasan Bentang Budaya, 1999), 50-51.
} 
While on the island of Java, the famous propagators of Islam are Walisongo. From the fame of the names of Walisongo in the midst of Indonesian Islamic society, it is an indicator that the spread of Islam in Indonesia can be accepted by Indonesian people through tarekat. Moreover, the attitude of life of the tarekat teachers who favor the interests of the people, so that the name and teachings are very influential in the formation of Islamic thought among the people and the ruling elite in the archipelago (nusantara). ${ }^{21}$

The position of sinden in the tandhe' is only a test of the faith of a penandhe', so when all movements are completed, a penandhe' will turn his body backward. This shows that even though being seduced by a beautiful girl, a person will never be tempted so symbolized by turning his body from a sinden. Then it ends by showing the sinden. This means that thank you for being a tempter, but can never be tempted because only God is in his heart. The meaning of karawitan and the tandhe' movement shows the form of monotheism to God by means of the movements in the tandhe' dance which the penandhe' now does not understand. Whereas the existence of musical and tandhe' movements essentially tells us to get closer to God. So it can also be said to preach (da'wah) with art. Ilustration of Tandhe' Karawitan Instruments (2019):

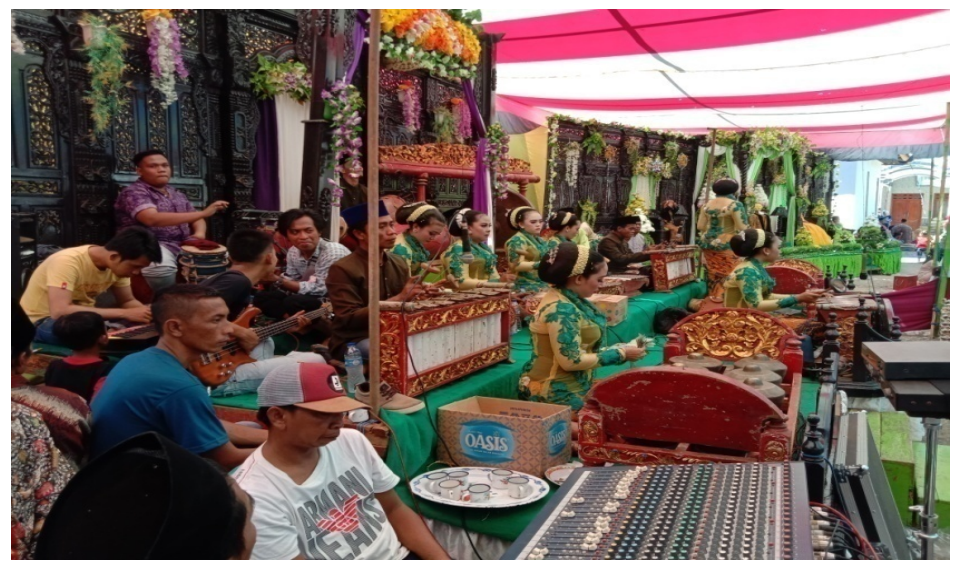

${ }^{21}$ J. Spencer Trimingham, The Sufi Order in Islam (London: Oxford University Press, 1973), 130. 


\section{Conclusion}

Since the emergence of tandhe' art until now experiencing a shift in the function and purpose of dance art tandhe' itself. At the time of Walisongo and the kings used to dance tandhe' functioned as a propaganda media used by Walisongo in order to spread Islamic teachings. But over time the religious value of the tandhe' dance began to fade because the lovers of the tandhe' dance began to abandon the teachings taught by Walisongo so that the tandhe' dance was an entertainment art aimed at worldly purposes only. In other words, the tandhe' performance at the present is not in line with the beginning of the formation of sinden art (tandhe') by Walisongo but instead leads to merely matereialism and entertainment.

Construction of meaning in the art of tandhe' excluded in the dance movement of tandhe' because every movement is exhibited by tandhe' there has a good meaning that looks like it or not. The construction of meaning in tandhe' exists in the number and sound of musical instruments. This means that when the instrument is played not only aims to be pleasant to hear but more than that contained Islamic moral messages and unity to God.

There are 3 symbolic communications in the dance of tandhe' used by Walisongo in preaching Islam to the public. First, the symbol of tirakat (penance) which is required of women who want to learn tandhe' must be fasting (at the first time) for one week and have to master 30 letters, namely letters Alif to Ya' (in Arabic). Second, there are tandhe' movements that show the greatness and oneness of God. Third, another element which is a symbolic interaction in the dance of tandhe' is a musical instrument which is also worthy of preaching and monotheism to God both in terms of movement, sound and in terms of numbers.

\section{References}

Abdullah, Haswah. Perkembangan Ilmu Tasawuf dan Tokoh-tokohnya di Nusantara. Surabaya: Al-Ikhlas. 2015.

Alifuddin, Muhammad. "Dakwah Berbasis Budaya Lokal Telaah atas Nilai-Nilai Dakwah dalam Folksong Orang Wakatobi." Al Munzir 
6, no. 1 (2013):72-89. https://ejournal.iainkendari.ac.id/almunzir/ article/ download/234/506.

Bernard, Raho. Teori Sosiologi Modern. Jakarta: Prestasi Pustaka. 2007. Blumerand, Herbert, and George Herbert Mead. Pengantar Sosiologi Mikro. Translated by Agus Salim. Yogyakarta: Pustaka Pelajar. 2008.

Cahyono, Agus. "Pola Kewarisan Nilai-nilai Kesenian Tayub (Inheritance Pattern of Tayub Value)." Harmoni Jurnal Pengetahuan dan Seni 1, (Januari-April 2006). https://journal. unnes.ac.id/nju/index.php/harmonia/article/download/746/680

Chatib, Quzwain. Mengenai Allah, Suatu Studi Mengenai Ajaran Tasawuf Syaikh Abdus Samad Al-Palimbani. Jakarta: Bulan Bintang. 1985.

Dahlan, Abdul Aziz. "Pembelaan terhadap Wahdat Al-Wujud: Tasawuf Syamsudin Sumatrani." Ulumul Qur'an 3, no.3 (1992).

Dwi Larasati, Evi. "Bentuk dan Makna Simbolik Tayub Rukun Karya dalam Rangkaian Ritual Rokat Tase' Masyarakat Desa Tanjung Selatan Kecamatan Saronggi Kabupaten Sumenep." Jurnal Apron. https://jurnalmahasiswa.unesa.ac.id/index.php/apron/article/view $/ 15556$.

Elvinaro, Ardianto, and Bambang Q-Anees. Bambang. Filsafat Ilmu Komunikasi. Bandung: Simbiosa Rekatama Media. 2007.

Hadi W.M., Abdul. “Syekh Hamzah Fansuri.” Ulumul Qur'an 5, no. 4 (1994).

Hadi, Sumandiyo. Aspek-Aspek Koreografi Kelompok. Yogyakarta: Manthili. 1996.

Hamzah, Zayadi. "Islam dalam Perspektif Budaya Lokal: Studi Tentang Ritual Siklus Hidup Keluarga Suku Rejang.” PhD prop.diss. UIN Syarif Hidayatullah Jakarta, 2008.

Indriyanto, Paparan Mata Kuliah Analisis Tari. Semarang: Diklat Jurusan Seni Drama,Tari dan Musik Fakultas Bahasa dan Seni Universitas Negeri Semarang. 2012.

Jazuli, M. Pendidikan Seni Budaya Suplemen Pembelajaran Seni Tari. Semarang: Universitas Negeri Semarang Press, 2008.

Kuntowijoyo. Budaya \& Masyarakat. Yogyakarta: Tiara Wacana Yogya. 1999. 
Kusmayati, Hermien. 'Arak-Arakan' Seni Pertunjukan dalam upacara Tradisional di Madura. Yogyakarta: Tarawang Press. 2000.

Ma'arif, Bambang S. Komunikasi Dakwah, Paradigma untuk Aksi. Bandung: Remaja Rosdakarya. 2010.

Machmiyah, Siti. "Interaksi Simbolik Santri Pondok Pesantren AlAmin." Jurnal Kajian Ilmu Komunikasi 45, no. 1 (2015).

Miles, M.B, and A.M. Huberman. Analisis Data Kualitatif. Translated by Rohid Jakarta: UI Press, 1992.

Mukti Ali, Beberapa Persoalan Agama Dewasa Ini. Jakarta: Rajawali Press, 1987.

Mulyana, Metode Penelitian Komunikasi. Bandung: PT Remaja Rosdakarya, 2007.

Murgiyanto. A Primer for Choreographers (Jakarta: Lembaga Pendidikan Kesenian Jakarta. 1977.

Murgiyanto. Seni Menata Tari. Jakarta: Dewan Kesenian Jakarta. 1983. Nawawi, Hadari, and Nini Martini. Penelitian Terapan. Yogyakarta : Gdajah Mada University Press. 1994.

Neuman, W. Laurence. Social Research Methods: Qualitative and Quantitative Approaches. Boston: Allyn and Bacon. 2000.

Nurhasanah, Een. "Nilai-Nilai Kearifan Lokal dalam Tiga Nyanyian Pembuka Pertunjukan Tari Jaipong." Paper presented at Seminar Nasional Pendidikan FKIP UNTIRTA (2017). https://jurnal.un tirta.ac.id/index.php/psnp/article/view/431-436.

Ritzer, George, and Douglas J. Goodman. Pengantar Sosiologi. Jakarta:

Penerbitan Fakultas Ekonomi Universitas Indonesia. 2004.

Rosmana, Tjetjep. "Kajian Cerita Rakyat Lampung." Jurnal Penelitian 40, no. 2 (Agustus 2008).

Simuh. Sufisme Transformasi Tasawuf Islam ke Mistik Jawa. Yogyakarta: Yayasan Bentang Budaya. 1999.

Trimingham, J. Spencer. The Sufi Order in Islam. London: Oxford University Press. 1973. 